\title{
Molecular farming on rescue of pharma industry for next generations
}

\author{
Khaled Moustafa ${ }^{*}$, Abdullah Makhzoum, Jocelyne Trémouillaux-Guiller
}

\begin{abstract}
Recombinant proteins expressed in plants have been emerged as a novel branch of the biopharmaceutical industry, offering practical and safety advantages over traditional approaches. Cultivable in various platforms (i.e. open field, greenhouses or bioreactors), plants hold great potential to produce different types of therapeutic proteins with reduced risks of contamination with human and animal pathogens. To maximize the yield and quality of plant-made pharmaceuticals, crucial factors should be taken into account, including host plants, expression cassettes, subcellular localization, posttranslational modifications, and protein extraction and purification methods. DNA technology and genetic transformation methods have also great parts of substantial improvements. To play their proper function and stability, proteins require multiple post-translational modifications such as glycosylation. Intensive glycoengineering researches have been performed to reduce the immunogenicity of recombinant proteins produced in plants. Important strategies have also been developed to minimize proteolysis effects and enhance protein accumulation. With growing human population and new epidemic threats, the need to new medications will be paramount that the traditional pharma industry wouldn't afford alone for upcoming generations. Here, we review several aspects of plant molecular pharming and outline some important challenges that hamper this ambitious biotechnology.
\end{abstract}

Keywords: molecular farming; molecular pharming; plant made pharmaceuticals; recombinant proteins; plant glycans; plant molecular farming; genetically modified plant; PMF; PMF; molecular farming applications; protein stability; therapeutic drug.

\section{Introduction}

Plant molecular pharming/farming (PMP/PMF) refers to the production of therapeutic proteins in genetically modified (GM) plant materials. The concept is not new. The ability of plants to express human genes has been demonstrated in 1986 (Barta et al. 1986). Since then, several mammalian proteins have been expressed in plants, and different plant species have gained great attention for their potentiality to express plant-made pharmaceuticals (PMPs) at reduced costs compared with conventional systems based on bacteria, yeast, insect or animal cell cultures (Paul and Ma 2011). Plants also allow nonnative proteins to be properly assembled, folded and glycosylated, and they offer flexible scalability with low risk of contamination with human pathogens (Yusibov et al. 2011). The first pharmaceutical plant-made protein produced in plants was a human growth hormone (hGH) expressed in transgenic tobacco and sunflower callus (Barta et al. 1986). A few years later (in 1990), 
another recombinant protein, the human serum albumin, was produced in transgenic tobacco and potato (Sijmons et al. 1990). Later on, many other recombinant proteins have been synthetized in engineered plants.

PMF is becoming a lucrative biotechnology industry with increasing number of specialized startup and biotechnology companies worldwide. An international society for plant molecular farming has recently been created and announced its first inaugural conference in Germany (Paul 2015). In the upcoming years, new health threats and complex diseases such as cancer and degenerative disorders would require complex therapeutic solutions (Andrianantoandro 2014). Here, we shed light on multiple facets of plant molecular pharming as one of the potential solutions with special focus on challenges, advantages and drawbacks related to this innovative system as a prospective rescue for traditional pharma industry to insure decent health treatments for next generations.

\section{Applications of PMFs}

The applications of PMF vary from basic research purposes (i.e. quantitative and qualitative characterization) to preventive (vaccines) and therapeutic purposes (drugs). The focus of PMF technology is to produce enzymes, growth factors, antibodies, vaccines and medicines for the treatment of major health challenges, chronic and infectious diseases (Stoger et al. 2014). Plant-made therapeutic products have recently been reported in experimental endeavors against major diseases, such as malaria (Gregory and Mayfield 2014) Alzheimer (Rosales-Mendoza et al. 2014) and many human and animal viruses (Rybicki 2014). In 2012, a high-profile drug called Elelyso ${ }^{\mathrm{TM}}$ (taliglucerase alfa) was approved in the USA as the first plant-made biodrug for the treatment of the type 1 Gaucher's disease, a rare genetic disorder. Monocots and dicots plant species, as well as moss and algae are able to express various proteins from animal or human origins. Therapeutic molecules (for ex. full antibodies or antibody fragments) (Fig. 1) can be produced successfully in genetically engineered plants. Vaccines have also been attempted for expression in plants (vegetables or fruits. The major benefit to produce biodrugs in edible crops is that, therapeutic molecules can be delivered orally in easy diets with consumed plant materials, reducing thus the overall costs and minimizing the downstream processing. In veterinary applications, the production of vaccines directly in forage would help to protect animals against viral diseases (Dus Santos and Wigdorovitz 2005). In this context, Dow AgroSciences (http://www.dowagro.com), a company specialized in agricultural biotechnology, has announced in 2006 the production of its first plant-made vaccine against chicken Newcastle disease virus.

\section{PFM production platforms}

The suitability of plants as viable systems to produce therapeutic proteins depends on different factors, including the type of the recombinant protein, the transformation and regeneration process, the culture mode, the upstream and downstream processing, and the overall cost. A good choice of plant host should also take into account the consequences of 


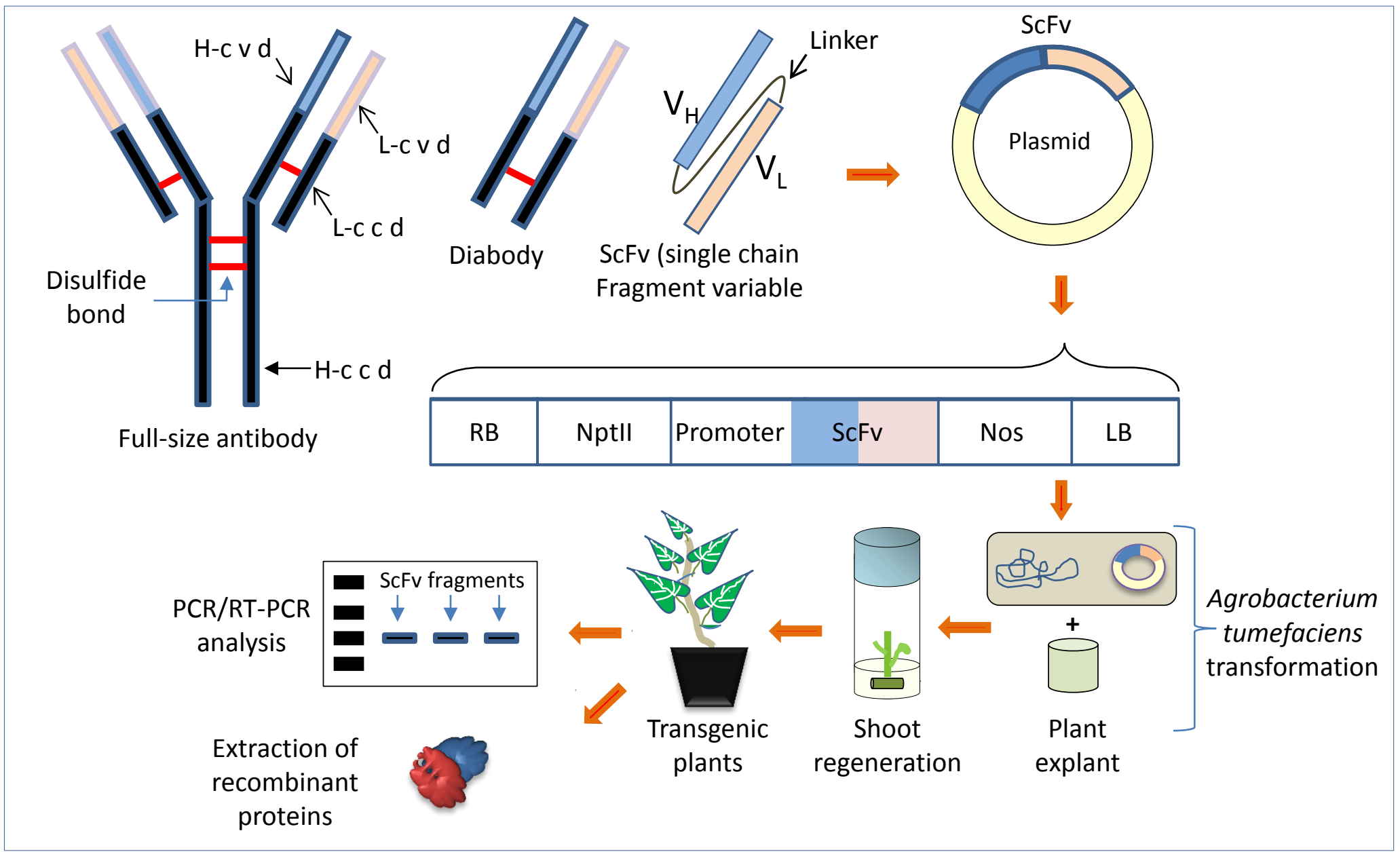

Figure 1. Schematic representation of the production of antibodies in plants via Agrobacterium tumefaciens-mediated transformation.

Full size antibody, diabody or single chain fragment variable (ScFv) can be engineered in an optimized expression cassette in Agrobacterium tumefaciens. Plants are then transformed by A. tumefaciens to regenerate transgenic plant harboring the antibody of interest. The presence of the protein in plant tissues can be confirmed by PCR/RT-PCR analysis prior to the purification of the recombinant protein from plant materials.

Abbreviations: L-cvd: light-chain variable domain; H-cvd: heavy-chain variable domain; L-ccd: light-chain constant domain; and H-ccd: heavy-chain constant domain; LB: left boarder; Nptll: neomycin phosphotransferase II gene conferring resistance to kanamycin and used as selectable marker for plant transformation; ScFv: single chain fragment variable; Nos: nopaline synthase; RB: right boarder. 
the chosen plant on the surrounding environment, human health, food safety and availability. Pharmaceutical proteins can be targeted to be produced in various plant platforms discussed below.

\subsection{Food/feed crops}

Leafy crops: Owing to important biomass and high contents of soluble proteins, leafy crops can be advantageously used in the production of recombinant proteins, despite proteolytic activities present in mature leaves which may reduce the final protein yield ( Pillay et al. 2014). This hurdle, however, can be circumvented by rapid processing of leaves immediately upon harvest and by protecting recombinant proteins from development-dependent proteolysis in leaves (Robert et al. 2013). Other important leafy crops include lettuce, alfalfa, and soybean. Recently, lettuce was tested to produce a multiepitopic HIV protein (C4(V3)6) that has shown high immunogenic potential compared with E. coli-derived C4(V3)6 (GoveaAlonso et al. 2013). Lettuce was also used to produce proinsulin (Boyhan and Daniell 2011), immunogenic F1-V fusion protein as a vaccine against plague (Rosales-Mendoza et al. 2010), cholera toxin B subunit ( al. 2007).

By their ability to fix the atmospheric nitrogen, legumes offer crucial environmental advantages to reduce the need to use artificial fertilizers. Harvestable up to nine times per year, alfalfa can be a good choice in plant molecular pharming with high accumulation levels of recombinant proteins, such as antibodies with $\mathrm{N}$-glycosylation, which is homogenous and suitable for glyco-engineering into human-compatible structures (Bardor et al. 2003).

Seeds: Seeds are an important platform for the production of pharmaceutical proteins particularly in developing countries where they allow increasing the availability of critical medicines for poor people and reduce the need for fermenters and cold chains for storage and distribution, decreasing the overall costs of the production system (Sabalza et al. 2013). Cereals such as maize, barley, rice and wheat are important seed food crops that accumulate high levels of proteins (Shewry and Halford 2002). Different seed tissues such as endosperm, cotyledons and scutellum can be targeted to produce long-term stable recombinant proteins of all types (short and long polypeptides, complex, noncontiguous proteins like antibodies etc.) (Boothe et al. 2010). With its large size of kernel (up to $82 \%$ of the endosperm), maize is one of the major cereal crops to produce high-value biopharmaceuticals (Naqvi et al. 2011). The presence of enzymes such as disulfide isomerases and chaperones insures proper folding of proteins in maize seeds (Ramessar et al. 2008), which have been used to produce different pharmaceuticals such as the recombinant HIV-neutralizing monoclonal antibody 2F5 (Sabalza et al. 2012) and the recombinant antibody 2G12 (Rademacher et al. 2008). However, the production of recombinant proteins in maize entails a potential risk of contamination due to cross-pollination and pollen dispersal. To avoid such dispersal risks, other self-pollinated crops such as barley and legumes species can be used. Barley is currently used for example to produce human-like growth factor and cytokine 
(http://www.orfgenetics.com). Soybean seeds are a practical host for the production of functional vaccines ( $\mathrm{Hudson}$ et al. 2014) and the accumulation of functional recombinant human coagulation factor IX (Cunha et al. 2011). Rice seeds also offer great potential for plant-made pharmaceuticals as an oral delivery system (Wakasa and Takaiwa 2013). Fieldgrown rice is used by Ventria Biosciences (http://www.ventria.com) to produce human lysozyme and lactoferrin (Faye and Gomord 2010). Despite these achievements, seeds may hold lower overall protein yields compared to vegetative tissues that are harvestable several times per year, which is not the case of seeds.

\subsection{Non-food/non-feed crops}

Many PMF products may raise health issues to consumers or livestock animals, if present in food/feed crops (Alderborn et al. 2010). The use of non-food/non-feed crops in PMF could thus be a good alternative to avoid such concerns. Among the most popular nonfood/non-feed crops used in plant molecular pharming is tobacco that offers important advantages including well-established transgenic techniques, year-round growth, important leaf biomass, large-scale infrastructure and easy harvest approaches. Nicotiana-based PMF platforms may also help to address major global health challenges related to high costs, limited manufacturing capacity and long manufacturing lead times (Whaley et al. 2011). The possibility to harvest tobacco leaves before flowering stage offers additional advantages to reduce potential gene leakage risk through pollen and seed dispersion. Protalix has recently introduced a new system called ProCellEx ${ }^{\circledR}$ as a recombinant protein expression system based on tobacco and carrot cell cultures to produce a wide range of complex proteins for the treatment of diverse diseases. Recently, a new experimental therapy, called ZMapp ${ }^{\mathrm{TM}}$, composed of three monoclonal antibodies was also successfully produced in tobacco by Mapp Biopharmaceutical (http://www.mappbio.com). ZMapp is one of the potential emerging options that was used during the recent outbreak of Ebola virus (Bishop 2015)

\subsection{Non-crop plants}

The number of non-crop plants used in molecular farming is still limited. However, key advantages of the plant model Arabidopsis, such as a short generation cycle and availability of extensive genetic tools, may allow using Arabidopsis in the future for commercial production of therapeutic proteins. So far, some studies reported the use of Arabidopsis for the production of recombinant HIV-1/HBV virus-like particles ( 2007), active human glucocerebrosidase ( $\mathrm{He}$ et al. 2012), and immunogenic VP2 protein of infectious bursal disease virus (Wu et al. 2004).

\subsection{Cell suspensions}

The expression of recombinant proteins in cell suspensions is an important technology used in PMF. Basic and applied researches using plant cell suspensions for different purposes have been explored for decades (Shih and Doran 2009). Cell suspension systems combine the advantages of whole-plants with those of bacteria or mammalian cells cultured in bioreactors (Xu and Kieliszewski 2012). Cell suspensions combine the advantages 
of whole-plants with those of bacteria or mammalian cells cultured in bioreactors ( $\underline{\mathrm{Xu} \text { and }}$ Kieliszewski 2012). Recombinant proteins expressed in cell suspensions can be synthesized at high levels and either retained in the intracellular compartments or secreted into the culture medium, facilitating the purification of the target proteins (Schillberg et al. 2013). However, recombinant proteins secreted in the culture medium may be degraded by proteases activities present in the culture medium (Doran 2006), decreasing the overall output of the recombinant proteins.

\subsection{Duckweeds and mosses}

Duckweeds (Lemna minor) are aquatic higher plants with fast clonal growth, easy harvest, high protein contents and effective capacity to express complex proteins (Stomp 2005). A proprietary clinically validated expression technology based on cultures of duckweed, called LEX SystemSM, is currently undertaken by Synthon (www.synthon.com/) for the development of pharmaceutical proteins such as glycan-engineered monoclonal antibodies, biosimilars, and veterinary medicines. A novel controlled-release of IFN-alpha2b (Locteron) was previously produced in Lemna in attempt to treat hepatitis $\mathrm{C}$ (phase II clinical trial) (Paul and Ma 2011)

. On other hand, mosses, in particular Physcomitrella patens, are small flowerless plants able to express complex human recombinant proteins in large photobioreactor settings (Decker and Reski 2007). Mosses are currently used by Greenovation BioTech (http://www.greenovation.com) for the development of products for research use such as the human FGF7/keratinocyte growth factor (KGF).

\subsection{Microalgae}

One of the most studied microalgae species in PFM context is the Chlamydomonas reinhardtii for which an important molecular toolkit for cloning and expressing recombinant DNA has been developed (Rasala et al. 2010) (Ma et al. 2011 ). C. reinhardtii has been used to express some biopharmaceuticals such as an immunotoxin protein against cancer (Tran et al. 2013), a large single-chain (Isc) antibody directed against glycoprotein D of the herpes simplex virus (Mayfield et al. 2003) and a diabetes-associated autoantigen human glutamic acid decarboxylase (hGAD65) (Wang et al. 2008). Microalgae-based systems, nevertheless, suffer from challenging nuclear expression (Specht et al. 2010) and a lack of photobioreactors adaptable for maximized growth, homogeneous gas exchange and light diffusion, particularly for intensive algal cultures.

\subsection{Hairy roots}

Hairy root are a neoplastic proliferation of adventitious roots that result from natural transformation of plant cells with a Gram-negative soil bacterium, Agrobacterium rhizogenes. Hairy root arises from a stable insertion of T-DNA segment from the Agrobacterium root-inducing ( $\mathrm{Ri}$ ) plasmid into the nuclear genome of host plants. The origin loci comprised between two borders of T-DNA sequences can be replaced by heterologous genes of pharmaceuticals interest. Well-established hairy-root cultures offer the advantage 
to be propagated indefinitely in liquid mediums and under sterile conditions without risk of transgene dissemination in surrounding environment (Guillon et al. 2006). However, hairy roots cultures from different species of Solanaceae seemed to have varying capacities to produce heterologous proteins such as the E. coli B-subunit heat-labile toxin antigen (Guzman et al. 2011).

\section{$4 \quad$ Plant engineering for recombinant proteins}

Recombinant DNA technology has facilitated the development of genetic systems to express foreign proteins in plants. To palliate natural tendency of proteins degradation in nonnative environments, an optimization is required at several levels, from gene insertion to protein purification.

\subsection{Heterologous gene insertion}

Upon the choice of target genes and host plants, gene insertion to the host genome can be carried out using conventional cloning systems with Agrobacterium tumefaciens or Agrobacterium rhizogenes, microparticle-coated DNA bombardment or viral vectors. Since three decades, Agrobacterium has been the dominant technology for producing genetically modified (GM) plant materials. Disarmed A. tumefaciens strains (i.e. T-DNA devoid of oncogenes) transform the host plant genome by transferring a recombinant T-DNA segment residing on a small, autonomous binary plasmid and functioning in trans to the vir region (Tzfira and Citovsky 2006). Plant virus expression vectors offer an innovative technology for the production of biopharmaceuticals in plant in relatively short time (Hefferon 2014). To overcome limitations related to low virus infectivity and inability to carry average-size or larger transgenes, a transfection technology called "magnifection" was developed, based on Agrobacterium as an infective system that delivers viral replicons (Agroviral hybrid vectors) (Gleba et al. 2005). Hybrid vectors that combine genetic elements of bacterial binary plasmids and viral vectors would have a substantial impact on the expression level of targeted recombinant proteins (Yusibov et al. 2013). Agroinfiltration, based on syringe and vacuum infiltration, would provide an efficient, robust and scalable gene-delivery system for commercial production of biodrugs in plants (Chen et al. 2013). However, targeting the nuclear genome to express foreign proteins is associated with some inconveniences including random insertion, instability of the transgene, sterility, and propagation risk of the transgene through pollens and low expression levels. To avoid such inconveniences, novel technologies have been developed to produce and recover recombinant proteins from plastids. The chloroplast genome, maternally inherited, reduces the risk of gene dispersal during pollination. Chloroplasts also allow proteins to fold, acquire disulfide bonds and gain their functions, though plastids cannot insure glycosylation of complex proteins plastid is not achieved, (Clarke et al. 2011). The high copy number of plastidial DNA (thousands of chloroplasts per cell) would produce high expression levels while reducing their potential toxicity for the cell. The cholera toxin B subunit (CTB) fused to human pro-insulin ( $A, B$ and $C$ peptides) was expressed in tobacco and lettuce chloroplasts with accumulation levels up to 
$47 \%$ and $53 \%$ total leaf protein, respectively (Boyhan and Daniell 2011). Higher accumulation ( 70\% TSP) was also reported in tobacco chloroplasts for proteinaceous antibiotic (Oey et al. 2009). A soluble, biologically active and properly folded form of human somatotropin was also expressed in tobacco with 300-fold in chloroplast compared with nuclear (Staub et al. 2000). However, PMF associated with plastid transformation has also some drawbacks, such as inefficient transformation method, rare paternal plastid transmission, and inability to insure human-like glycosylation ( $\mathrm{Ma}$ et al. 2003). It thus might be inappropriate to target proteins to chloroplasts if glycosylation is required for protein activity.

\subsection{Optimization of the transgene expression}

A good design of expression cassettes has an important impact on the transcription and translation of recombinant proteins in plants. An expression cassette is minimally composed of a cloning site, promoter and 3' UTR (untranslated regions). Other regulatory elements may could be included upstream or downstream the promoter, to boost the transcriptional machinery. The choice of gene promoter is a crucial factor in the expression of recombinant proteins since it binds, and interacts with, trans-acting factors to positively or negatively regulate the activity of the driven gene. Promoters can be used from natural origin (plant or virus) or assembled synthetically to regulate gene expression in constitutive, tissue-specific or inducible manners. It was reported that soybean polyubiquitin promoter gives strong constitutive expression in transgenic soybean (Hernandez-Garcia et al. 2009). CaMV35S promoter used to drive the expression of Escherichia coli B-subunit heat-labile toxin (LTB) in hairy roots produced a high yield of LTB, though reduced biomass and growth retardation were observed (Guzman et al. 2011). The chimeric super-promoter TEV (tobacco etch virus) is also a powerful expression system in tobacco hairy roots system (Nopo et al. 2012).

Tissue-specific promoters, such as leaf-specific $r b c S$, chloroplast-specific $p s b A$ and $16 S$ ribosomal RNA (Prrn) promoters can be considered as potential alternatives to constitutive promoters (Ruhlman et al. 2007, Corrado and Karali 2009). When the efficiency of constitutive and root-specific promoters was compared to drive expression of human interferon alpha-2b in transgenic carrot (Luchakivskaya et al. 2011), it was found that interferon accumulated at higher levels in roots than in leaves under control of the rootspecific MIl promoter, but inversely when it was under control of constitutive $35 \mathrm{~S}$ promoter (Luchakivskaya et al. 2011). Seed-specific promoters, such as the soybean seed-specific glycinin and endosperm-specific glutelin promoters are also used to target heterologous proteins to particular parts of the seed (Tiwari et al. 2009).

Inducible promoters provide an important strategy for transgenes expression in plants with modular transcriptional activity by chemicals (such as tetracycline) or physical agents (such as temperatures or desiccation).

Another strategy to increase the transcription levels is to stack together multiple transcription units to reinforce the transcription machinery (Streatfield 2007). Gene expression level also depends on the position, the number of transgenes copy, the silencing and optimization processes. Codon optimization, however, may play positive or negative 
role in the transcription and translation of heterologous proteins (Lico et al. 2012). For example, the codon optimization of the surface antigen SAG178-322, from Toxoplasma gondii, demonstrates that the codon optimization does not always result in an improved expression level, where the optimized codon of SAG1 resulted in an accumulation level 5- to 10-fold lower than a non-optimized codon (Laguia-Becher et al. 2010).

A new comprehensive and optimized cloning strategy called GoldenBraid 2.0 (GB2.0) was recently developed (Sarrion-Perdigones et al. 2013). GB2.0 system is based on the use of restriction enzymes (type IIS) to foster the exchange and assembly of DNA fragments to generate fully exchangeable genetic elements and provide an open collection of genetic material, including constitutive and inducible expression cassettes, endogenous gene silencing and protein-protein interaction investigation tools (Sarrion-Perdigones et al. 2013). To maintain long stability and activity of proteins at ambient temperatures, transgenes can be targeted to plant storage organs such as seeds (cereals, corn) or tubers (potato) where proteins benefit from long-term adequate regulations. For example, targeting the human coagulation factor IX ( $h F I X)$ to be expressed in soybean seeds resulted in an accumulation of the coagulation factor up to $0.8 \mathrm{~g} / \mathrm{Kg}$ seeds, with functional stable activity up to 6 years (Cunha et al. 2011).

\section{Protein glycosylation}

Glycosylation is a covalent binding of sugars (glycans) to polypeptides. About two thirds of proteins are predicted to be $\mathrm{N}$-glycosylated for their proper folding, activity and stability (Apweiler et al. 1999). Antibodies, cytokines, enzymes and gonadotrophins hold their functions depending on particular glycoforms (Gomord et al. 2010). The production of glycosylated proteins in molecular pharming is dominated by mammalian production systems, able to ensure appropriate glycosylation similarly to human glycosylation (Ghaderi et al. 2012). Subcellular compartments may also influence the protein glycosylation profiles; the same protein expressed in different compartments or tissues may exhibit different glycosylation patterns (De Muynck et al. 2009).

\subsection{Plant glycosylation versus mammalian glycosylation}

Plants are able to synthesize complex proteins with different posttranslational rearrangements such as $\mathrm{N}$-glycosylation required for folding and functioning of many eukaryotic proteins. Plant $\mathrm{N}$-glycosylation starts in the ER by co- or posttranslational transfer of oligosaccharide precursor (Glc3 Man9 Glc NAc2) via polyisoprenoid lipid carrier (SaintJore-Dupas et al. 2007). The covalent attachment of oligosaccharides to polypeptide backbone is achieved with two main linkages: $\mathrm{N}$-glycans (where oligosaccharide is bound to amide group of asparagine or arginine residues) or O-glycans (where oligosaccharide bound to hydroxyl group of threonine, serine or hydroxyproline residues).

$\mathrm{O}$-glycan and $\mathrm{N}$-glycan modifications take place in Golgi apparatus. There is a difference between animals and plants in regard to this process. In plant, the glycosylation is achieved by the attachment of $\alpha(1,3)$ fucose and $\beta(1,2)$ xylose to the $N$-glycan of their glycoproteins, 
while in animals, the glycosylation is achieved by the attachment of $\alpha(1,6)$ fucose moieties, glucose, or acid sialic residues (Wilson 2002, Obembe et al. 2011). Oligosaccharides present in most human glycoproteins are capped by addition of sialic acid (or Neuraminic acid) on a penultimate galactose residue (Saint-Jore-Dupas et al. 2007). Plants, on the other hand, lack $\mathrm{N}$-acetyl neuraminic acid. The inability of plants to perform authentic $\mathrm{N}$-glycosylation is one of the obstacles that obstruct the use of plant-made monoclonal antibodies in therapy (Jin et al. 2008). In fact, plant-glycosylated antibodies may cause immunogenicity and allergenicity in the administrated human subjects, though no strong evidence was reported so far that plant glycans are harmful to humans (Fischer et al. 2012). Jin et al, (2008) found that plantderived human monoclonal antibody (2G12) induces an anti-carbohydrate immune response in rabbits. Four $2 \mathrm{G} 12$ glycoforms that differ in the presence/absence of $\beta(1,2)$ xylose and $\alpha$ $(1,3)$ fucose were generated and expressed in glyco-engineered plant lines. Immunizing rabbits with the different versions of plant-glycolysated antibody provided evidence for adverse effects of non-mammalian $\mathrm{N}$-glycan modifications produced in plants (Jin et al. 2008). However, it should be noted that $\mathrm{CHO}$ (Chinese hamster ovary) cell line produces non-human glycans, knowing that hamster is a mammalian species (Fischer et al. 2012).

\subsection{Humanization of plant glycoproteins}

In recent years, glycoengineering research made it possible to humanize plant-made glycoproteins and reduce their immunogenicity for mammals. Several approaches are used for this purpose to adapt the human $\mathrm{N}$-glycosylation pattern in plants: $i$ ) binding of ERretention signal KDEL to only high mannose-type N-glycan (Floss et al. 2009), ii) generating of knock-out mutants that synthesize $\mathrm{N}$-glycans without immunogenic epitopes (xylose or fucose) (Koprivova et al. 2004), or iii) inactivation of glycosyltransferases (Sourrouille et al. 2008). In the latter case, for example, the inactivation of endogenous glycosyltransferases by antisense or RNAi approaches allowed the production of glycovariants in alfalfa with reduced immunogenicity for mammals (Sourrouille et al. 2008). The authors knocked out two specific $\mathrm{N}$-glycan enzymes ( $\beta 1$, 2-xylosyltransferase and $\alpha 1$, 3-fucosyltransferases), then they expressed the human $\beta 1$, 4-galactosyltransferase either in its native form or in fusion with $\mathrm{N}$-acetyl glucosaminyltransferase targeting domain. They found that the activity of the recombinant human $\beta 1$, 4-galactosyltransferase prevented the accumulation of the Lewis $\alpha$ glycoepitope on the complex N-glycans (Sourrouille et al. 2008). The action of glycosyltransferases $\beta 1,4$ galactosyltransferase and sialyltransferase, naturally present in mammals, produces galactosylated and sialyted N-glycans (Fischer et al. 2012).

Protein sialylation is another potential approach to humanize plant-made proteins (Castilho et al. 2010). Sialic acid residues can be added to a protein and enhance the binding of macromolecules to initiate its biological activity (Byrne et al. 2007).

\section{Mechanisms affecting the protein stability}

The final yield of a recombinant protein is the overall differences between its biosynthesis and proteolysis rates. Although proteolysis is a natural biological turnover process, hence 
hardly avoidable (Faye et al. 2005), several mechanisms can minimize its effects on protein life cycles. One of these mechanisms is to target the foreign protein into some plant organs, tissue types or subcellular compartments where the microenvironment is not, or poorly, favorable for proteolysis (De Muynck et al. 2009). The subcellular location in which the protein acquires post-translational modifications has a significant impact on yield and stability of the protein ( $\mathrm{Ma}$ et al. 2003). The physiological conditions in cellular compartments such as the $\mathrm{pH}$ and salt concentrations can accelerate or inhibit the protease activity. Given these considerations, vacuole, ER and seeds have proven to be effective targets to produce long-term stable pharmaceuticals. For example, targeting of the human insulin-like growth factor-I (hIGF-I) to the rice seeds resulted in an enhanced yield and stability of the hIGF-I (Cheung et al. 2011). Soybean seeds were also used to produce stable forms of human proinsulin and coagulation factor XI under the control of seed-specific promoters and $\alpha$-coixin signal peptide (Cunha et al. 2011).

Another mechanism to increase protein stability is to reduce the protease activity in the production system by targeting proteins to be secreted into the culture media enriched by protease inhibitors or stabilizing agents such as gelatin, BSA (bovine serum albumin), DMSO (dimethyl sulfoxide), PVP (Polyvinyl-pyrrolidone) and PEG (polyethylene glycol) (Doran 2006). Endogenous protease activity could also be suppressed using protease-deficient cell lines, generated either by gene knockout, gene silencing, or RNA interference approaches (Kim et al. 2008). Using an RNAi potato line for example, impaired in ATP transporter and starch production, increased the yield of recombinant protein up to 4 -fold (Tremblay et al. 2011). The co-expression of proteinase inhibitors alongside with the targeted proteins is another option to enhance protein stability ( $\mathrm{Kim}$ et al. 2008). Alternative strategies involve the optimization of the chemical and physical conditions of the production system. At high $\mathrm{pH}$, it was shown that the human recombinant $\alpha(1)$-antitrypsin (AAT) and the human serum albumin (HSA) presented improved stability patterns (Sun et al. 2011).

Protein stability can also be enhanced by designing specific expression system such as the hyper-translatable cowpea mosaic virus expression system (CPMV-HT). This system was recently used to produce the human serum albumin ( $\mathrm{rHSA}$ ) in tobacco BY-2 cells with yield up to $11.88 \mu \mathrm{g} / \mathrm{mL}$ (Sun et al. 2011). A movement-defective cucumber mosaic virus (CMV) was also developed to produce an anti-dioxin single chain variable fragment, DxscFv, and interleukin-1 receptor antagonist in tobacco (Fukuzawa et al. 2011).

Protein fusion to specific tags could also be employed to increase protein stability. Particularly, the fusion of specific domains is an important approach to stabilize short peptides. For example, the tetramerisation domain (TD) fused to the short viral peptide $2 \mathrm{~L} 21$ stabilizes this highly immunogenic peptide when expressed in tobacco chloroplasts (Ortigosa et al. 2010). It is, however, worthy to note that the degradation rates of therapeutic IgG antibodies expressed in tobacco plants or cell suspensions increase with leaf aging and 
culture duration (De Muynck et al. 2009). Optimized shortened culture periods and recovering recombinant proteins from young leaves would reduce the degradation rates.

\section{Purification of recombinant proteins}

The extraction and purification of recombinant proteins can be laborious and costly. Compared to mammalian and bacterial based-systems, protein production in plants is generally less expensive. Plant-made biopharmaceuticals may need only partial, or not all, purification step especially when they are targeted to be produced in edible plant parts (Schillberg et al. 2005). Protein extraction may be required in some cases to avoid toxic alkaloids present in some plant species or tissues. Depending on the production-systems being used (whole plant, plant tissue, or cell suspensions) the protein purification requires a series of laborious steps: (1) harvest of plant materials, (2) extraction of total proteins, and (3) purification of the target recombinant protein. Protein purification methods can be based on chromatography or non-chromatography approaches.

\subsection{Chromatography methods}

Chromatography-based methods are generally expensive and hardly scalable. They are based on ion exchange, gel filtration, reverse-phase chromatography or affinity chromatography. The combination of two or more of these methods is also possible. For example, both immobilized metal-ion affinity chromatography (IMAC) and gel filtration methods were used to purify a candidate vaccine destined to treat the human papillomavirus (HPV16) with high purity up to $99 \%$ and yield up to $0.1 \mathrm{~g}$ per $1 \mathrm{Kg}$ plant biomass (Buyel et al. 2012). The recombinant construct contained the subunit E7 GGG of HPV16, fused to hexa-His- and KDEL-tagged variants of the bacterial lichenase. Erlendsson et al., (2010) have also combined sequential chromatography approach based on IMAC affinity and cation exchange to purify an active human Flt3 ligand from barley seeds. Flt3 was fused to HQ-tag and expressed in barley seeds where it undergoes glycosylation and acquires its biological activity, which was comparable to commercialized Flt3 (Erlendsson et al. 2010).

\subsection{Non-chromatography methods}

Protein purification methods based on non-chromatography approaches are relatively simple, easily scalable and cost-effective compared to chromatography methods. They are based on the use of ELP (elastin-like protein), hydrophobin, zein, and oleosin-based fusion tags. ELP approach consists in the fusion of the heterologous protein to short fungal peptides. The recombinant protein is then recovered by a series of selective and reversible processes known as Inverse Transition Cycling (ITC) that includes sequential steps of precipitation, salting, heating, centrifugation and resolubilization (Meyer and Chilkoti 1999). Recent findings highlight the potential of ELP-intein coupling system as a cost-effective purification approach at industrial level (Tian and Sun 2011). To improve ELP-based purification methods, some modifications have been suggested. One of them is to substitute 
sodium chloride for ammonium sulfate which results in the possibility to perform ELP purification at room temperature (Fong et al. 2009). Another substitution is to replace the centrifugation step by a microfiltration step to reduce any potential proteolysis due to mechanical cleavage, during the centrifugation step, and to maintain high protein stability and activity (Ge et al. 2006). Using this modified approach, two avian flu H5N1 antigens have been recently purified from transgenic tobacco (Phan and Conrad 2011). The attachment of cysteine-rich and low-molecular mass hydrophobin family members is another method to facilitate the protein purification. The attachment of hydrophobin HFBI for example to GFP resulted in the accumulation of the recombinant HFBI-GFP up to $51 \%$ of the TSP (Joensuu et al. 2012). The maize proline-rich domain, Zera, is also used as a purification tag in densitybased purification approach. The advantage of using such a domain is that it forms protein aggregates that can accumulate in the ER. Zera-fused approach was recently used to purify Xylanase enzyme from transgenic tobacco (Llop-Tous et al. 2011)._More simple and costeffective approach consists in the fusion of target molecules to oleosin proteins to enhance the accumulation of the target proteins onto the surface of the oil bodies. Although this approach is limited to oilseed crops, it was recently attempted to purify human insulin-like growth factor 1 (hIGF-1) from Arabidopsis seeds (Li et al. 2011).

Protein-extraction methods from plant materials are developing at accelerated pace. Synthesized proteins in plant-cell culture system could be retained within cells or secreted to the culture medium. However, the removal of cell debris and other undesirable compounds is a challenge for the protein purification step. Strong expression systems using double viral vectors allow increasing the ratio of "target molecule/secondary metabolites" (Werner et al. 2011). Another option of optimization of the purification of recombinant proteins could be through a multistage thermofluor screening, based on the improvement of global purification parameters (such as temperature, $\mathrm{pH}$, salt concentration, etc.,) and the use of small molecules that specifically binds to target protein to increase their stability (Boivin et al. 2013). Overall, the cheapest way of protein extraction, however, would remain to target the recombinant proteins to edible parts of plants, so they can be delivered in a dietary regime and no purification step would be needed except for concentration purposes and/or industrial packing. However, although targeting recombinant proteins in edible crops is relatively cheap and easy way, the idea of using edible plants directly as vaccine should be considered with caution due to potential problems associated with adequate dosage of the medication and the potential for inadvertent mixing with material destined for food or feed chain. Thus, this approach will probably be limited to specific drugs and host systems where these potential problems are less relevant, or alternatively non-food/non-feed crops should be considered in such cases.

\section{Clinical trials and commercialization of plant-made pharmaceuticals}

Twenty years after the first antibody produced in plants, many other recombinant products, particularly antibodies, cytokines and vaccines have been manufactured in engineered plants 
for diagnostic, prevention and therapeutic purposes. However, plant-derived biodrugs industry is still in its infancy relative to the great potential of plants as natural and effective production systems for highly valuable molecules of medicinal interest, but things are changing at accelerated pace. Producing plant-derived pharmaceuticals according to high standards has been reinforced in term of purity, consistency, and biosafety of the recombinant proteins, particularly proteins extracted from plants growing in non-sterile or partially controlled environments. Active research and rapid developments in PMPs are enduring in hundreds of research centers, biotech companies and universities worldwide and many plant-made pharmaceuticals are currently available either at trial or approval stages (Table 1). For example, the recombinant human pro-insulin, intended to treat the type 1 diabetes, is produced in tobacco and lettuce and currently at trial phase (Boyhan and Daniell 2011). Gastric lipase and tumor-specific antibodies are also available on the marketplace ( $\mathrm{Ma}$ et al. 2005). Gastric lipase is intended to treat exocrine pancreatic insufficiency syndrome (diagnosed in an autosomal recessive disease called cystic fibrosis) and tumor antibody is destined to treat non-Hodgkin's lymphoma. Other antigenic determinants from bacteria and viruses responsible for numerous pathologies such as anthrax, rabies, cancer (Pujol et al. 2007), diphtheria, tetanus, tuberculosis, malaria are also produced in transgenic plants (Sharma and Sharma 2009).

\section{Conclusion}

The production of recombinant proteins in transgenic plants for pharmaceutical, veterinary and industrial purposes is one of the most promising challenges of molecular pharming. Compared with other protein production systems, plants offer crucial advantages including rapid scalability, low cost and significantly reduced risk for human contamination. So far, many important biopharmaceuticals have been produced in plant-based pharming systems. Major shortcomings, however, still need to be circumvented such as the low production levels of proteins, the high rate of proteolysis and the biosafety and public acceptability issues related to the potential dispersal of transgenes to non-target organisms.. Higher plants are also unable to properly process mammalian $\mathrm{N}$-glycans to insure full functionality of the recombinant proteins. The absence of solid and reliable platform pattern also delay the industrial implementation of plant-derived biopharmaceuticals to insure high yield and standard quality of valuable biodrugs.. Each of these concerns needs to be treated on a case-by-case basis involving the host plant and the target protein. .

To reduce immunogenicity and allergenicity disorders relating to plant-made drugs, glycoengineering research should be enhanced to generate plant lines that can carry out authentic glycosylation similarly to human cells. To optimize the extraction/purification methods, special attention is required to prevent or, at least, to minimize the proteolysis trend of heterologous proteins. Good manufacturing practices (GMPs) implying purity, consistency, efficiency, and biosafety of the plant-made pharmaceuticals are also key factors that should be taken into account for an effective-cost and reliable plant molecular 
pharming platform. GMP is indeed a key consideration in plant molecular farming. It is probably the main reason why production of pharmaceuticals via cultivation of GM plants in the field is considered problematic. Indeed, maintaining batch-to-batch consistency in the quality of a product appears very difficult in field conditions due to the influence of environmental factors. Although many biosafety issues of GM crops apply equally to PMPs (Sparrow and Twyman 2009), additional factors proper to PMPs need to be addressed to ensure that the desired products are consistently expressed in the correct formats, extracted, assembled and stored efficiently and safely.. The stable insertion of transgenes into nuclear or plastidial genome and the optimization of gene expression systems may also help enhancing the post-translational stability and increase the overall protein yield. The choice of plant tissue, organ and cellular compartments to express and accumulate proteins of interest has strong influence on the integrity and the functionality of the final product. With growing human population, the demands of biopharmaceuticals will increase considerably to answer growing human needs for the treatment of various pathologies and new threats. Plant molecular pharming holds effective promises, and it opens large avenues to be explored to reinforce the traditional pharmaceutical industry for improving human welfare.

\section{Disclosure: None.}

\section{References}

Alderborn, A., J. Sundstrom, D. Soeria-Atmadja, M. Sandberg, H. C. Andersson and U. Hammerling (2010). "Genetically modified plants for non-food or non-feed purposes: straightforward screening for their appearance in food and feed." Food Chem Toxicol 48(2): 453-464.

Andrianantoandro, E. (2014). "Next-generation therapeutics." Trends Biotechnol 32(9): 431-432.

Apweiler, R., H. Hermjakob and N. Sharon (1999). "On the frequency of protein glycosylation, as deduced from analysis of the SWISS-PROT database." Biochim Biophys Acta 1473(1): 4-8.

Bardor, M., C. Loutelier-Bourhis, T. Paccalet, P. Cosette, A. C. Fitchette, L. P. Vezina, S. Trepanier, M. Dargis, R. Lemieux, C. Lange, L. Faye and P. Lerouge (2003). "Monoclonal C5-1 antibody produced in transgenic alfalfa plants exhibits a $\mathrm{N}$-glycosylation that is homogenous and suitable for glycoengineering into human-compatible structures." Plant Biotechnol J 1(6): 451-462.

Barta, A., K. Sommergruber, D. Thompson, K. Hartmuth, M. A. Matzke and A. J. Matzke (1986). "The expression of a nopaline synthase - human growth hormone chimaeric gene in transformed tobacco and sunflower callus tissue." Plant Mol Biol 6(5): 347-357.

Basaran, P. and E. Rodriguez-Cerezo (2008). "Plant molecular farming: opportunities and challenges." Crit Rev Biotechnol 28(3): 153-172.

Bishop, B. M. (2015). "Potential and Emerging Treatment Options for Ebola Virus Disease." Ann Pharmacother 49(2): 196-206. 
Boivin, S., S. Kozak and R. Meijers (2013). "Optimization of protein purification and characterization using Thermofluor screens." Protein Expr Purif 91(2): 192-206.

Boothe, J., C. Nykiforuk, Y. Shen, S. Zaplachinski, S. Szarka, P. Kuhlman, E. Murray, D. Morck and M. M. Moloney (2010). "Seed-based expression systems for plant molecular farming." Plant Biotechnol J 8(5): 588-606.

Boyhan, D. and H. Daniell (2011). "Low-cost production of proinsulin in tobacco and lettuce chloroplasts for injectable or oral delivery of functional insulin and C-peptide." Plant Biotechnol J 9(5): 585-598.

Buyel, J. F., J. A. Bautista, R. Fischer and V. M. Yusibov (2012). "Extraction, purification and characterization of the plant-produced HPV16 subunit vaccine candidate E7 GGG." Journal of Chromatography B 880(0): 19-26.

Byrne, B., G. G. Donohoe and R. O'Kennedy (2007). "Sialic acids: carbohydrate moieties that influence the biological and physical properties of biopharmaceutical proteins and living cells." Drug Discov Today 12(7-8): 319-326.

Capodicasa, C., P. Chiani, C. Bromuro, F. De Bernardis, M. Catellani, A. S. Palma, Y. Liu, T. Feizi, A. Cassone, E. Benvenuto and A. Torosantucci (2011). "Plant production of anti-beta-glucan antibodies for immunotherapy of fungal infections in humans." Plant Biotechnol J 9(7): 776-787.

Castilho, A., R. Strasser, J. Stadlmann, J. Grass, J. Jez, P. Gattinger, R. Kunert, H. Quendler, M. Pabst, R. Leonard, F. Altmann and H. Steinkellner (2010). "In planta protein sialylation through overexpression of the respective mammalian pathway." J Biol Chem 285(21): 15923-15930.

Chen, Q., H. Lai, J. Hurtado, J. Stahnke, K. Leuzinger and M. Dent (2013). "Agroinfiltration as an Effective and Scalable Strategy of Gene Delivery for Production of Pharmaceutical Proteins." Advanced techniques in biology \& medicine 1(1): 103.

Cheung, S. C., L. Z. Liu, L. L. Lan, Q. Q. Liu, S. S. Sun, J. C. Chan and P. C. Tong (2011). "Glucose lowering effect of transgenic human insulin-like growth factor-I from rice: in vitro and in vivo studies." BMC Biotechnol 11: 37.

Clarke, J. L., H. Daniell and J. M. Nugent (2011). "Chloroplast biotechnology, genomics and evolution: current status, challenges and future directions." Plant Mol Biol 76(3-5): 207-209.

Corrado, G. and M. Karali (2009). "Inducible gene expression systems and plant biotechnology." Biotechnology Advances 27(6): 733-743.

Cunha, N. B., A. M. Murad, G. L. Ramos, A. Q. Maranhao, M. M. Brigido, A. C. Araujo, C. Lacorte, F. J. Aragao, D. T. Covas, A. M. Fontes, G. H. Souza, G. R. Vianna and E. L. Rech (2011). "Accumulation of functional recombinant human coagulation factor IX in transgenic soybean seeds." Transgenic Res 20(4): 841-855.

D'Aoust, M. A., M. M. Couture, N. Charland, S. Trepanier, N. Landry, F. Ors and L. P. Vezina (2010). "The production of hemagglutinin-based virus-like particles in plants: a rapid, efficient and safe response to pandemic influenza." Plant Biotechnol J 8(5): 607-619. 
De Muynck, B., C. Navarre, Y. Nizet, J. Stadlmann and M. Boutry (2009). "Different subcellular localization and glycosylation for a functional antibody expressed in Nicotiana tabacum plants and suspension cells." Transgenic Res 18(3): 467-482.

Decker, E. L. and R. Reski (2007). "Moss bioreactors producing improved biopharmaceuticals." Curr Opin Biotechnol 18(5): 393-398.

Doran, P. M. (2006). "Foreign protein degradation and instability in plants and plant tissue cultures." Trends Biotechnol 24(9): 426-432.

Dus Santos, M. J. and A. Wigdorovitz (2005). "Transgenic plants for the production of veterinary vaccines." Immunol Cell Biol 83(3): 229-238.

Erlendsson, L. S., M. O. Muench, U. Hellman, S. M. Hrafnkelsdóttir, A. Jonsson, Y. Balmer, E. Mäntylä and B. L. Örvar (2010). "Barley as a green factory for the production of functional Flt3 ligand." Biotechnology Journal 5(2): 163-171.

Faye, L., A. Boulaflous, M. Benchabane, V. Gomord and D. Michaud (2005). "Protein modifications in the plant secretory pathway: current status and practical implications in molecular pharming." Vaccine 23(15): 1770-1778.

Faye, L. and V. Gomord (2010). "Success stories in molecular farming-a brief overview." Plant Biotechnol J 8(5): 525-528.

Fischer, R., S. Schillberg, S. Hellwig, R. M. Twyman and J. Drossard (2012). "GMP issues for recombinant plant-derived pharmaceutical proteins." Biotechnol Adv 30(2): 434-439.

Floss, D. M., M. Sack, E. Arcalis, J. Stadlmann, H. Quendler, T. Rademacher, E. Stoger, J. Scheller, R. Fischer and U. Conrad (2009). "Influence of elastin-like peptide fusions on the quantity and quality of a tobacco-derived human immunodeficiency virus-neutralizing antibody." Plant Biotechnol J 7(9): 899-913.

Fong, B. A., W. Y. Wu and D. W. Wood (2009). "Optimization of ELP-intein mediated protein purification by salt substitution." Protein Expr Purif 66(2): 198-202.

Frey, A. D., S. R. Karg and P. T. Kallio (2009). "Expression of rat beta(1,4)-Nacetylglucosaminyltransferase III in Nicotiana tabacum remodels the plant-specific N-glycosylation." Plant Biotechnol J 7(1): 33-48.

Fukuzawa, N., T. Ishihara, N. Itchoda, N. Tabayashi, C. Kataoka, C. Masuta and T. Matsumura (2011). "Risk-managed production of bioactive recombinant proteins using a novel plant virus vector with a helper plant to complement viral systemic movement." Plant Biotechnol J 9(1): 38-49.

Ge, X., K. Trabbic-Carlson, A. Chilkoti and C. D. Filipe (2006). "Purification of an elastin-like fusion protein by microfiltration." Biotechnol Bioeng 95(3): 424-432.

Ghaderi, D., M. Zhang, N. Hurtado-Ziola and A. Varki (2012). "Production platforms for biotherapeutic glycoproteins. Occurrence, impact, and challenges of non-human sialylation." Biotechnol Genet Eng Rev 28: 147-175.

Gleba, Y., V. Klimyuk and S. Marillonnet (2005). "Magnifection--a new platform for expressing recombinant vaccines in plants." Vaccine 23(17-18): 2042-2048. 
Gomord, V., A. C. Fitchette, L. Menu-Bouaouiche, C. Saint-Jore-Dupas, C. Plasson, D. Michaud and L. Faye (2010). "Plant-specific glycosylation patterns in the context of therapeutic protein production." Plant Biotechnol J 8(5): 564-587.

Govea-Alonso, D. O., N. Rubio-Infante, A. L. Garcia-Hernandez, J. T. Varona-Santos, S. S. Korban, L. Moreno-Fierros and S. Rosales-Mendoza (2013). "Immunogenic properties of a lettuce-derived C4(V3)6 multiepitopic HIV protein." Planta.

Greco, R., M. Michel, D. Guetard, M. Cervantes-Gonzalez, N. Pelucchi, S. Wain-Hobson, F. Sala and M. Sala (2007). "Production of recombinant HIV-1/HBV virus-like particles in Nicotiana tabacum and Arabidopsis thaliana plants for a bivalent plant-based vaccine." Vaccine 25(49): 8228-8240.

Gregory, J. A. and S. P. Mayfield (2014). "Developing inexpensive malaria vaccines from plants and algae." Appl Microbiol Biotechnol.

Guillon, S., J. Tremouillaux-Guiller, P. K. Pati, M. Rideau and P. Gantet (2006). "Hairy root research: recent scenario and exciting prospects - commentary " Curr Opin Plant Biol 9: 341-346.

Guzman, G., A. Walmsley, D. Webster and J. Hamill (2011). "Hairy roots cultures from different Solanaceous species have varying capacities to produce E. coli B-subunit heat-labile toxin antigen." Biotechnology Letters 33(12): 2495-2502.

He, X., J. D. Galpin, M. B. Tropak, D. Mahuran, T. Haselhorst, M. von Itzstein, D. Kolarich, N. H. Packer, Y. Miao, L. Jiang, G. A. Grabowski, L. A. Clarke and A. R. Kermode (2012). "Production of active human glucocerebrosidase in seeds of Arabidopsis thaliana complex-glycan-deficient (cgl) plants." Glycobiology 22(4): 492-503.

Hefferon, K. (2014). "Plant virus expression vector development: new perspectives." Biomed Res Int 2014: 785382.

Hernandez-Garcia, C., A. Martinelli, R. Bouchard and J. Finer (2009). "A soybean (Glycine max) polyubiquitin promoter gives strong constitutive expression in transgenic soybean." Plant Cell Reports 28(5): 837-849.

Hudson, L. C., R. Garg, K. L. Bost and K. J. Piller (2014). "Soybean seeds: a practical host for the production of functional subunit vaccines." Biomed Res Int 2014: 340804.

Huy, N. X., M. S. Yang and T. G. Kim (2011). "Expression of a cholera toxin B subunit-neutralizing epitope of the porcine epidemic diarrhea virus fusion gene in transgenic lettuce (Lactuca sativa L.)." Mol Biotechnol 48(3): 201-209.

Jin, C., F. Altmann, R. Strasser, L. Mach, M. Schahs, R. Kunert, T. Rademacher, J. Glossl and H. Steinkellner (2008). "A plant-derived human monoclonal antibody induces an anti-carbohydrate immune response in rabbits." Glycobiology 18(3): 235-241.

Joensuu, J. J., A. J. Conley, M. B. Linder and R. Menassa (2012). "Bioseparation of recombinant proteins from plant extract with hydrophobin fusion technology." Methods Mol Biol 824: 527-534.

Kaiser, J. (2008). "Is the drought over for pharming?" Science 320(5875): 473-475. 
Karg, S. R. and P. T. Kallio (2009). "The production of biopharmaceuticals in plant systems." Biotechnol Adv 27(6): 879-894.

Kim, N.-S., T.-G. Kim, O.-H. Kim, E.-M. Ko, Y.-S. Jang, E.-S. Jung, T.-H. Kwon and M.-S. Yang (2008). "Improvement of recombinant hGM-CSF production by suppression of cysteine proteinase gene expression using RNA interference in a transgenic rice culture." Plant Mol Biolo 68(3): 263-275.

Kim, T.-G., H.-J. Lee, Y.-S. Jang, Y.-J. Shin, T.-H. Kwon and M.-S. Yang (2008). "Co-expression of proteinase inhibitor enhances recombinant human granulocyte-macrophage colony stimulating factor production in transgenic rice cell suspension culture." Protein Expr Purif 61(2): 117-121.

Koprivova, A., C. Stemmer, F. Altmann, A. Hoffmann, S. Kopriva, G. Gorr, R. Reski and E. L. Decker (2004). "Targeted knockouts of Physcomitrella lacking plant-specific immunogenic N-glycans." Plant Biotechnol J 2(6): 517-523.

Laguia-Becher, M., V. Martin, M. Kraemer, M. Corigliano, M. Yacono, A. Goldman and M. Clemente (2010). "Effect of codon optimization and subcellular targeting on Toxoplasma gondii antigen SAG1 expression in tobacco leaves to use in subcutaneous and oral immunization in mice." BMC Biotechnol 10(1): 52 .

Lau, O. S., D. W. Ng, W. W. Chan, S. P. Chang and S. S. Sun (2010). "Production of the 42-kDa fragment of Plasmodium falciparum merozoite surface protein 1 , a leading malaria vaccine antigen, in Arabidopsis thaliana seeds." Plant Biotechnol J 8(9): 994-1004.

Li, W., L. Li, K. Li, J. Lin, X. Sun and K. Tang (2011). "Expression of biologically active human insulin-like growth factor 1 in Arabidopsis thaliana seeds via oleosin fusion technology." Biotechnol Appl Biochem 58(3): 139-146.

Lico, C., L. Santi, R. M. Twyman, M. Pezzotti and L. Avesani (2012). "The use of plants for the production of therapeutic human peptides." Plant Cell Rep 31(3): 439-451.

Llop-Tous, I., M. Ortiz, M. Torrent and M. D. Ludevid (2011). "The expression of a xylanase targeted to ER-protein bodies provides a simple strategy to produce active insoluble enzyme polymers in tobacco plants." PLoS One 6(4): e19474.

Luchakivskaya, Y., O. Kishchenko, I. Gerasymenko, Z. Olevinskaya, Y. Simonenko, M. Spivak and M. Kuchuk (2011). "High-level expression of human interferon alpha-2b in transgenic carrot (Daucus carota L.) plants." Plant Cell Rep 30(3): 407-415.

Ma, J. K., E. Barros, R. Bock, P. Christou, P. J. Dale, P. J. Dix, R. Fischer, J. Irwin, R. Mahoney, M. Pezzotti, S. Schillberg, P. Sparrow, E. Stoger, R. M. Twyman and C. European Union Framework 6 Pharma-Planta (2005). "Molecular farming for new drugs and vaccines. Current perspectives on the production of pharmaceuticals in transgenic plants." EMBO Rep 6(7): 593-599.

Ma, J. K., P. M. Drake and P. Christou (2003). "The production of recombinant pharmaceutical proteins in plants." Nat Rev Genet 4(10): 794-805.

Ma, S., A. M. Jevnikar and N. P. A. Hüner (2011). "Microalgae as Bioreactors for Production of Pharmaceutical Proteins " Comprehensive Biotechnology, Second Edition 4 301-307.

Mayfield, S. P., S. E. Franklin and R. A. Lerner (2003). "Expression and assembly of a fully active antibody in algae." Proc Natl Acad Sci U S A 100(2): 438-442. 
Meyer, D. E. and A. Chilkoti (1999). "Purification of recombinant proteins by fusion with thermallyresponsive polypeptides." Nat Biotechnol 17(11): 1112-1115.

Naqvi, S., K. Ramessar, G. Farre, M. Sabalza, B. Miralpeix, R. M. Twyman, T. Capell, C. Zhu and P. Christou (2011). "High-value products from transgenic maize." Biotechnol Adv 29(1): 40-53.

Nopo, L., B. J. Woffenden, D. G. Reed, S. Buswell, C. Zhang and F. Medina-Bolivar (2012). "Superpromoter:TEV, a powerful gene expression system for tobacco hairy roots." Methods Mol Biol 824: 501-526.

Obembe, O. O., J. O. Popoola, S. Leelavathi and S. V. Reddy (2011). "Advances in plant molecular farming." Biotechnol Adv 29(2): 210-222.

Oey, M., M. Lohse, B. Kreikemeyer and R. Bock (2009). "Exhaustion of the chloroplast protein synthesis capacity by massive expression of a highly stable protein antibiotic." Plant J 57(3): 436-445.

Ortigosa, S., A. Fernández-San Millán and J. Veramendi (2010). "Stable production of peptide antigens in transgenic tobacco chloroplasts by fusion to the p53 tetramerisation domain." Transgenic Res 19(4): 703-709.

Paul, M. (2015). "International Society for Plant Molecular Farming : 1st Conference, Berlin-Dahlem, Germany, 17th-19th June 2014." Transgenic Res.

Paul, M. and J. K. Ma (2011). "Plant-made pharmaceuticals: leading products and production platforms." Biotechnol Appl Biochem 58(1): 58-67.

Phan, H. T. and U. Conrad (2011). "Membrane-based inverse transition cycling: an improved means for purifying plant-derived recombinant protein-elastin-like polypeptide fusions." Int J Mol Sci 12(5): 2808-2821.

Pillay, P., U. Schluter, S. van Wyk, K. J. Kunert and B. J. Vorster (2014). "Proteolysis of recombinant proteins in bioengineered plant cells." Bioengineered 5(1): 15-20.

Pujol, M., J. Gavilondo, M. Ayala, M. Rodriguez, E. M. Gonzalez and L. Perez (2007). "Fighting cancer with plant-expressed pharmaceuticals." Trends Biotechnol 25(10): 455-459.

Rademacher, T., M. Sack, E. Arcalis, J. Stadlmann, S. Balzer, F. Altmann, H. Quendler, G. Stiegler, R. Kunert, R. Fischer and E. Stoger (2008). "Recombinant antibody 2 G12 produced in maize endosperm efficiently neutralizes HIV-1 and contains predominantly single-GIcNAc N-glycans." Plant Biotechnol J 6(2): 189-201.

Ramessar, K., M. Sabalza, T. Capell and P. Christou (2008). "Maize plants: An ideal production platform for effective and safe molecular pharming." Plant Sci 174(4): 409-419.

Rasala, B. A., M. Muto, P. A. Lee, M. Jager, R. M. Cardoso, C. A. Behnke, P. Kirk, C. A. Hokanson, R. Crea, M. Mendez and S. P. Mayfield (2010). "Production of therapeutic proteins in algae, analysis of expression of seven human proteins in the chloroplast of Chlamydomonas reinhardtii." Plant Biotechnol J 8(6): 719-733. 
Robert, S., M. Khalf, M. C. Goulet, M. A. D'Aoust, F. Sainsbury and D. Michaud (2013). "Protection of recombinant mammalian antibodies from development-dependent proteolysis in leaves of Nicotiana benthamiana." PLoS One 8(7): e70203.

Rosales-Mendoza, S., N. Rubio-Infante, S. Zarazua, D. O. Govea-Alonso, G. Martel-Gallegos and L. Moreno-Fierros (2014). "Plant-based vaccines for Alzheimer's disease: an overview." Expert Rev Vaccines 13(3): 429-441.

Rosales-Mendoza, S., R. E. Soria-Guerra, L. Moreno-Fierros, A. G. Alpuche-Solis, L. Martinez-Gonzalez and S. S. Korban (2010). "Expression of an immunogenic F1-V fusion protein in lettuce as a plantbased vaccine against plague." Planta 232(2): 409-416.

Ruhlman, T., R. Ahangari, A. Devine, M. Samsam and H. Daniell (2007). "Expression of cholera toxin Bproinsulin fusion protein in lettuce and tobacco chloroplasts--oral administration protects against development of insulitis in non-obese diabetic mice." Plant Biotechnol J 5(4): 495-510.

Rybicki, E. P. (2014). "Plant-based vaccines against viruses." Virol J 11(1): 205.

Sabalza, M., L. Madeira, C. van Dolleweerd, J. K. Ma, T. Capell and P. Christou (2012). "Functional characterization of the recombinant HIV-neutralizing monoclonal antibody $2 \mathrm{F5}$ produced in maize seeds." Plant Mol Biol 80(4-5): 477-488.

Sabalza, M., E. Vamvaka, P. Christou and T. Capell (2013). "Seeds as a production system for molecular pharming applications: status and prospects." Curr Pharm Des 19(31): 5543-5552.

Saint-Jore-Dupas, C., L. Faye and V. Gomord (2007). "From planta to pharma with glycosylation in the toolbox." Trends Biotechnol 25(7): 317-323.

Sarrion-Perdigones, A., M. Vazquez-Vilar, J. Palaci, B. Castelijns, J. Forment, P. Ziarsolo, J. Blanca, A. Granell and D. Orzaez (2013). "GoldenBraid 2.0: a comprehensive DNA assembly framework for plant synthetic biology." Plant Physiol 162(3): 1618-1631.

Schillberg, S., N. Raven, R. Fischer, R. M. Twyman and A. Schiermeyer (2013). "Molecular farming of pharmaceutical proteins using plant suspension cell and tissue cultures." Curr Pharm Des 19(31): 5531-5542.

Schillberg, S., R. M. Twyman and R. Fischer (2005). "Opportunities for recombinant antigen and antibody expression in transgenic plants--technology assessment." Vaccine 23(15): 1764-1769.

Sharma, A. K. and M. K. Sharma (2009). "Plants as bioreactors: Recent developments and emerging opportunities." Biotechnology Advances 27(6): 811-832.

Shewry, P. R. and N. G. Halford (2002). "Cereal seed storage proteins: structures, properties and role in grain utilization." J Exp Bot 53(370): 947-958.

Shih, S. M. H. and P. M. Doran (2009). "Foreign protein production using plant cell and organ cultures: Advantages and limitations." Biotechnology Advances 27(6): 1036-1042.

Sijmons, P. C., B. M. Dekker, B. Schrammeijer, T. C. Verwoerd, P. J. van den Elzen and A. Hoekema (1990). "Production of correctly processed human serum albumin in transgenic plants." Biotechnology (N Y) 8(3): 217-221. 
Sourrouille, C., E. Marquet-Blouin, M. A. D'Aoust, M. C. Kiefer-Meyer, M. Seveno, S. PagnySalehabadi, M. Bardor, G. Durambur, P. Lerouge, L. Vezina and V. Gomord (2008). "Down-regulated expression of plant-specific glycoepitopes in alfalfa." Plant Biotechnol J 6(7): 702-721.

Sparrow, P. A. and R. M. Twyman (2009). "Biosafety, risk assessment and regulation of plant-made pharmaceuticals." Methods Mol Biol 483: 341-353.

Specht, E., S. Miyake-Stoner and S. Mayfield (2010). "Micro-algae come of age as a platform for recombinant protein production." Biotechnol Lett 32(10): 1373-1383.

Staub, J. M., B. Garcia, J. Graves, P. T. Hajdukiewicz, P. Hunter, N. Nehra, V. Paradkar, M. Schlittler, J. A. Carroll, L. Spatola, D. Ward, G. Ye and D. A. Russell (2000). "High-yield production of a human therapeutic protein in tobacco chloroplasts." Nat Biotechnol 18(3): 333-338.

Stoger, E., R. Fischer, M. Moloney and J. K. Ma (2014). "Plant molecular pharming for the treatment of chronic and infectious diseases." Annu Rev Plant Biol 65: 743-768.

Stomp, A. M. (2005). "The duckweeds: a valuable plant for biomanufacturing." Biotechnol Annu Rev 11: 69-99.

Streatfield, S. J. (2007). "Approaches to achieve high-level heterologous protein production in plants." Plant Biotechnol J 5(1): 2-15.

Sun, Q.-Y., L.-W. Ding, G. P. Lomonossoff, Y.-B. Sun, M. Luo, C.-Q. Li, L. Jiang and Z.-F. Xu (2011). "Improved expression and purification of recombinant human serum albumin from transgenic tobacco suspension culture." J Biotechnol 155(2): 164-172.

Tian, L. and S. S. Sun (2011). "A cost-effective ELP-intein coupling system for recombinant protein purification from plant production platform." PLoS One 6(8): e24183.

Tiwari, S., P. C. Verma, P. K. Singh and R. Tuli (2009). "Plants as bioreactors for the production of vaccine antigens." Biotechnology Advances 27(4): 449-467.

Tran, M., C. Van, D. J. Barrera, P. L. Pettersson, C. D. Peinado, J. Bui and S. P. Mayfield (2013). "Production of unique immunotoxin cancer therapeutics in algal chloroplasts." Proc Natl Acad Sci U S A 110(1): E15-22.

Tremblay, R., H. Diao, N. Huner, A. M. Jevnikar and S. Ma (2011). "The development of a high-yield recombinant protein bioreactor through RNAi induced knockdown of ATP/ADP transporter in Solanum tuberosum." J Biotechnol 156(1): 59-66.

Tzfira, T. and V. Citovsky (2006). "Agrobacterium-mediated genetic transformation of plants: biology and biotechnology." Curr Opin Biotechnol 17(2): 147-154.

Vianna, G. R., N. B. Cunha, A. M. Murad and E. L. Rech (2011). "Soybeans as bioreactors for biopharmaceuticals and industrial proteins." Genet Mol Res 10(3): 1733-1752.

Wakasa, Y. and F. Takaiwa (2013). "The use of rice seeds to produce human pharmaceuticals for oral therapy." Biotechnology Journal 8(10): 1133-1143. 
Wang, X., M. Brandsma, R. Tremblay, D. Maxwell, A. M. Jevnikar, N. Huner and S. Ma (2008). "A novel expression platform for the production of diabetes-associated autoantigen human glutamic acid decarboxylase (hGAD65)." BMC Biotechnol 8: 87.

Werner, S., O. Breus, Y. Symonenko, S. Marillonnet and Y. Gleba (2011). "High-level recombinant protein expression in transgenic plants by using a double-inducible viral vector." Proc Natl Acad Sci U S A 108(34): 14061-14066.

Whaley, K. J., A. Hiatt and L. Zeitlin (2011). "Emerging antibody products and Nicotiana manufacturing." Hum Vaccin 7(3): 349-356.

Wilson, I. B. (2002). "Glycosylation of proteins in plants and invertebrates." Curr Opin Struct Biol 12(5): 569-577.

Wu, H., N. K. Singh, R. D. Locy, K. Scissum-Gunn and J. J. Giambrone (2004). "Expression of immunogenic VP2 protein of infectious bursal disease virus in Arabidopsis thaliana." Biotechnol Lett 26(10): 787-792.

Xu, J. and M. J. Kieliszewski (2012). "A novel plant cell bioproduction platform for high-yield secretion of recombinant proteins." Methods Mol Biol 824: 483-500.

Yusibov, V., S. J. Streatfield, N. Kushnir, G. Roy and A. Padmanaban (2013). "Hybrid viral vectors for vaccine and antibody production in plants." Curr Pharm Des 19(31): 5574-5586.

Yusibov, V., S. J. Streatfield and N. Kushnir (2011). "Clinical development of plant-produced recombinant pharmaceuticals: vaccines, antibodies and beyond." Hum Vaccin 7(3): 313-321. 
Table 1. Examples of plant-made biopharmaceuticals at various clinical phases.

\begin{tabular}{|c|c|c|c|c|c|c|}
\hline $\begin{array}{l}\text { Biopharmace } \\
\text { utical Product }\end{array}$ & $\begin{array}{l}\text { Disease or } \\
\text { indication }\end{array}$ & $\begin{array}{l}\text { Plant } \\
\text { system }\end{array}$ & $\begin{array}{l}\text { Clinical } \\
\text { status }\end{array}$ & Reference & Company & URL \\
\hline $\begin{array}{l}\text { Recombinant } \\
\text { human } \\
\text { insulin (SBS- } \\
1000 \text { ) }\end{array}$ & Diabetes & $\begin{array}{l}\text { Safflower } \\
\text { s } \\
\text { (seeds) }\end{array}$ & $\begin{array}{l}\text { Phases II } \\
\text { complete. } \\
\text { Phase III in } \\
\text { progress }\end{array}$ & $\begin{array}{l}\text { (Frey et al. } \\
\text { 2009) } \\
\text { (Fischer et al. } \\
\text { 2012) }\end{array}$ & $\begin{array}{l}\text { SemBioSys } \\
\text { Genetics Inc. } \\
\text { (Canada) }\end{array}$ & \\
\hline BLX & $\begin{array}{l}\text { Non- } \\
\text { Hodgkin's } \\
\text { Lymphoma }\end{array}$ & $\begin{array}{l}\text { Duckwee } \\
\text { d }\end{array}$ & Phase II & $\begin{array}{l}\text { (Fischer et al. } \\
\text { 2012) }\end{array}$ & $\begin{array}{l}\text { Biolex Inc. } \\
\text { (USA) }\end{array}$ & \\
\hline $\begin{array}{l}\text { Subunit } \\
\text { vaccine } \\
\text { (Avian } \\
\text { influenza- } \\
\text { H5) }\end{array}$ & $\begin{array}{l}\text { Influenza } \\
\text { (virus VLP) }\end{array}$ & Tobacco & $\begin{array}{l}\text { Phase II } \\
\text { complete }\end{array}$ & $\begin{array}{l}\text { (D'Aoust et al. } \\
\underline{2010})\end{array}$ & $\begin{array}{l}\text { Medicago } \\
\text { Inc. } \\
\text { (USA) }\end{array}$ & $\begin{array}{l}\text { http://www.med } \\
\text { icago.com }\end{array}$ \\
\hline $\begin{array}{l}\text { Antibody } \\
\text { against } \\
\text { hepatitis B \& } \\
\text { C }\end{array}$ & $\begin{array}{l}\text { Vaccine } \\
\text { purification }\end{array}$ & Tobacco & On market & (Kaiser 2008) & CIGB (Cuba) & \\
\hline $\begin{array}{l}\text { Cancer } \\
\text { vaccine }\end{array}$ & $\begin{array}{l}\text { Non- } \\
\text { Hodgkin's } \\
\text { Lymphoma }\end{array}$ & Tobacco & Phase II & & $\begin{array}{l}\text { Large Scale } \\
\text { Biology (USA) }\end{array}$ & $\begin{array}{l}\text { http://www.isbc. } \\
\underline{\text { com }}\end{array}$ \\
\hline Carer (IgG) & $\begin{array}{l}\text { Preventive of } \\
\text { tooth decay } \\
\text { (Dental } \\
\text { caries) }\end{array}$ & Tobacco & $\begin{array}{l}\text { Phase II } \\
\text { complete. } \\
\text { Approved for } \\
\text { human in } \\
\text { Europe }\end{array}$ & $\begin{array}{l}\text { (Frey et al. } \\
\text { 2009) } \\
\begin{array}{l}\text { (Paul and Ma } \\
\text { 2011) }\end{array}\end{array}$ & $\begin{array}{l}\text { Planet } \\
\text { Biotechnol. } \\
\text { Inc. } \\
\text { (Hayward, } \\
\text { USA) }\end{array}$ & $\begin{array}{l}\frac{\text { http://www.plan }}{\text { etbiotechnology. }} \\
\text { com }\end{array}$ \\
\hline $\begin{array}{l}\text { Glucocerebro } \\
\text { sidase } \\
\text { (Elelyso) }\end{array}$ & $\begin{array}{l}\text { Gaucher's } \\
\text { disease }\end{array}$ & Carrot & $\begin{array}{l}\text { approved, on } \\
\text { market } 2012\end{array}$ & $\begin{array}{l}\text { (Paul and Ma } \\
\underline{2011)}\end{array}$ & $\begin{array}{l}\text { Protalix Bio- } \\
\text { Therapeutics }\end{array}$ & $\begin{array}{l}\text { http://www.protali } \\
\underline{x . c o m}\end{array}$ \\
\hline $\begin{array}{l}\text { Avicidin } \\
\text { (Antibodies) }\end{array}$ & $\begin{array}{l}\text { Colorectal } \\
\text { cancer }\end{array}$ & Corn & Phase II & $\begin{array}{l}\text { (Basaran and } \\
\text { Rodriguez- } \\
\text { Cerezo 2008) }\end{array}$ & $\begin{array}{l}\text { NeoRX/Mons } \\
\text { anto (USA) }\end{array}$ & \\
\hline $\begin{array}{l}\text { Recombinant } \\
\text { Human } \\
\text { Lactoferrin } \\
\text { (VEN100) }\end{array}$ & $\begin{array}{l}\text { Gastrointesti } \\
\text { nal disorders }\end{array}$ & Rice & $\begin{array}{l}\text { Phase II } \\
\text { clinical trial }\end{array}$ & & $\begin{array}{l}\text { Ventria } \\
\text { Bioscience } \\
\text { (USA) }\end{array}$ & $\frac{\text { http://www.vent }}{\underline{\text { ria.com }}}$ \\
\hline $\begin{array}{l}\text { Full-length } \\
\text { recombinant } \\
\text { plasmin, Anti- } \\
\text { CD20 } \\
\text { antibody } \\
\text { (BLX-301) }\end{array}$ & $\begin{array}{l}\text { Acute } \\
\text { peripheral } \\
\text { arterial } \\
\text { disease, non- } \\
\text { Hodgkin's } \\
\text { lymphoma }\end{array}$ & $\begin{array}{l}\text { Duckwee } \\
\text { d }\end{array}$ & $\begin{array}{l}\text { Preclinical } \\
\text { development }\end{array}$ & $\begin{array}{l}\text { (Basaran and } \\
\text { Rodriguez- } \\
\text { Cerezo 2008) }\end{array}$ & $\begin{array}{l}\text { Biolex Inc. } \\
\text { (USA) }\end{array}$ & \\
\hline $\begin{array}{l}\text { Hepatitis B } \\
\text { antigen oral } \\
\text { vaccine }\end{array}$ & Hepatitis B & $\begin{array}{l}\text { Potato } \\
\text { Lettuce }\end{array}$ & $\begin{array}{l}\text { Phase II } \\
\text { Phase I }\end{array}$ & $\begin{array}{l}\text { (Lau et al. } \\
\underline{2010)}\end{array}$ & $\begin{array}{l}\text { Arizona } \\
\text { University, T. } \\
\text { Jefferson } \\
\text { University }\end{array}$ & \\
\hline $\begin{array}{l}\text { Recombinant } \\
\text { avidin }\end{array}$ & $\begin{array}{l}\text { Avidin } \\
\text { (Research \& } \\
\text { Diagnostic } \\
\text { reagent) }\end{array}$ & Maize & On market & $\begin{array}{l}\text { (Vianna et al. } \\
\underline{2011)}\end{array}$ & ProdiGene & \\
\hline
\end{tabular}




\begin{tabular}{|c|c|c|c|c|c|c|}
\hline MAPP66 & $\begin{array}{l}\text { Antibodies } \\
\text { (indicated as } \\
\text { combination } \\
\text { HSV/HIV } \\
\text { microbicide }\end{array}$ & $\begin{array}{l}\text { Tobacco } \\
\text { (Nicotian } \\
\text { a } \\
\text { bentham } \\
\text { iana) }\end{array}$ & Phase I & $\begin{array}{l}\text { (Fischer et al. } \\
\text { 2012) }\end{array}$ & $\begin{array}{l}\text { Bayer/ICON } \\
\text { Genetics }\end{array}$ & $\frac{\text { http://www.baye }}{\text { r-innovation.com }}$ \\
\hline $\begin{array}{l}\text { Locteron } \\
\text { (alpha- } \\
\text { interferon) } \\
\text { (IFN- } \square \text { ) }\end{array}$ & $\begin{array}{l}\text { Chronic } \\
\text { hepatitis C }\end{array}$ & $\begin{array}{l}\text { Lemna } \\
\text { (Duckwe } \\
\text { ed) }\end{array}$ & Phase II & $\begin{array}{l}\text { (Paul and Ma } \\
\underline{2011)}\end{array}$ & $\begin{array}{l}\text { Biolex } \\
\text { Therapeutics } \\
\text { (Pittsboro, } \\
\text { USA) }\end{array}$ & \\
\hline $\begin{array}{l}\text { Antibody } \\
\text { (indicated as } \\
\text { HIV } \\
\text { microbicide) }\end{array}$ & P2G12 & Tobacco & $\begin{array}{l}\text { Phase I in } \\
\text { progress }\end{array}$ & $\begin{array}{l}\text { (Fischer et al. } \\
\text { 2012) }\end{array}$ & $\begin{array}{l}\text { Pharma- } \\
\text { Planta (EU) }\end{array}$ & $\begin{array}{l}\text { http://www.phar } \\
\text { ma-planta.org }\end{array}$ \\
\hline $\begin{array}{l}\text { Antitumor } \\
\text { necrosis } \\
\text { factor } \\
\text { (Pr-anti-TNF) }\end{array}$ & Arthritis & Carrot & Pre-clinical & $\begin{array}{l}\text { (Paul and Ma } \\
\underline{2011)}\end{array}$ & Protalix & $\frac{\text { http://www.prot }}{\underline{\text { alix.com }}}$ \\
\hline $\begin{array}{l}\operatorname{lgG} 2 b(\mathrm{mAb} \\
2 \mathrm{G} 8)\end{array}$ & $\begin{array}{l}\text { Fungal } \\
\text { diseases }\end{array}$ & Tobacco & Pre-clinical & $\begin{array}{l}\text { (Capodicasa et } \\
\text { al. 2011) }\end{array}$ & $\begin{array}{l}\text { ENEA, UT } \\
\text { BIORAD } \\
\text { (Italy) }\end{array}$ & \\
\hline ZMapp & Ebola & Tobacco & ExperimeNtal & & Mapp Bio & $\begin{array}{l}\text { www.mappbio.c } \\
\text { om }\end{array}$ \\
\hline
\end{tabular}

*Email: khaled.moustafa@gmail.com 